\title{
Determinants of Rice Farmers' Investment in Value Addition and Its Effect on Poverty Status in Kebbi State, Nigeria
}

\author{
${ }^{*}$ A. S. Hussaini, Y. U, Oladimeji, S. A. Sanni and S. Abdulrahman \\ Department of Agricultural Economics, Ahmadu Bello University, Zaria, Nigeria \\ [Corresponding Author: E-mail: Huseesha@gmail.com; $8:+234(0) 7037869388,+2349022470334]$
}

\section{ABSTRACT}

The study examined investment of rice value addition activities among farmers in Kebbi State, Nigeria. Data used for the study were collected with the aid of structured questionnaire administered to 123 randomly selected farmers in three local government areas of the state. Data was analyzed using Foster Greek Thoerboeck (FGT) poverty index and logit regression technique. The results showed that poverty status among the rice farmers was high, as $58.3 \%$ were poor and $42.7 \%$ were non poor. The result of the analysis showed that the marginal effects of income from parboiling, winnowing, drying, destoning, and bagging value addition were negative and statistically significant related to farmer's poverty status at $1 \%$ level. It was concluded that rice farmers' investment in value addition should be promoted among the farmers in Kebbi State. High cost of labour (81.0\%), poor marketing information (75.6\%) and inadequate credit (73.1\%) were the three most critical constraints limiting the farmers in engaging in value addition activities. It was recommended that farmers cooperatives should form collaboration with extension agent to make farmers aware of the benefits of investment in value addition activities and those farmers already investing in value addition should make use of the modern method of processing instead of the traditional practices which help to increase their income.

Keywords: Investment, Value addition, Processing, Poverty status and Rice farmers.

\section{INTRODUCTION}

The agricultural sector of Nigerian economy contributes significantly to rural employment, food security and poverty alleviation (John et al., 2014.). The food crisis in Nigeria increase the demand for staple food, such as rice, and this has not been accompanied with corresponding rise in production and processing (Adu et al., 2012). It is suffices to note that most of the processing activities in the country are carried out on a small scale, usually without huge investment and complex processing techniques. Small enterprises in rural area, no doubt have close ties with the agricultural sector, especially food processing which rely heavily on local raw materials (Gyimah et al., 2016).

Rice, in particular, has been a key focal commodity, as consumption is estimated to be rising at $5.1 \%$ annually and is expected to reach 36 million metric tons (MT) by 2050 (Federal Ministry of Agriculture and Rural Development
FMARD 2011; Johnson and Masias, 2017). However, Nigerian rice sub-sector has witness some remarkable developments, particularly in the last few years due to federal government interventions. This culminated in dropped in rice importation by 300,000 tons in 2016 (United States Department of Agriculture, 2017). As oil accounts for $70 \%$ of the government's revenue in 2016 (US energy formation administration), a strategy to diversify the economy into agriculture has been implemented by recent administrations to reduce the strain on the country's foreign currency reserves due to the economic risks associated with volatile global oil prices. Furthermore, rice is an important food crop and serves as a food security commodity in Nigeria (Ala and Bello, 2010).

Rice sector being a critical sub-sector of agricultural sector can serve as a means of conserving foreign exchange and improve the nation's economy. Micro-enterprises, especially, 


\section{Hussaini et al: Determinants of Rice Farmers' Investment in Value Addition and Its Effect on.........}

those involving pre and post-harvest handling activities of agricultural materials have become major component of the economies of developing countries such as Nigeria (Isaac et al., 2016). Based on this assertion, development of food processing industries in Nigeria will not only improve food supplies but also reduce imports. Such move will contribute to increase selfreliance by reducing food losses, adding value to the raw materials, increasing export earnings, raising employment levels and improving incomes (Ige et al., 2016).

Value on the other hand implies worth, benefits price or measure of importance. It is a factor of utility. Value can also be seen as the monetary term in which the utility of a product or an item can be explained. Therefore, value addition in the production of rice implies all the activities, processes or strategies and distribution of rice which in one way or the other contribute to benefit/utility maximization (Ugwu et al., 2014).

The poverty reducing potential of value addition is not only in generating rural income and employment but also by improvement in processing that reduce traditional food preparation times (Obasi and Enyia, 2016). Furthermore, value addition also creates employment at low levels of investment that make effective use of local resources (Kindness and Gordon, 2001; John et al., 2014) and also creates vertical linkage with farmers that supply inputs (Ministry of Food and Agriculture MOFA, 2007; John et al., 2014). This draws the attention of various stakeholders in promoting agribusiness especially the agro-processing sector (MoFA 2007; John et al., 2014) maintains that growth in income of households is achievable through agro-processing.

Despite all the potentials of the agro-industrial sector of Nigeria, majority of rural farming households still depend basically on on-farm and non-farm activities for their livelihood (Oladimeji et al., 2015). However, one important means of income generation that rural farmers have not paid much attention to is value addition (Obasi and Enyia, 2016). Given the crucial role of rice in the food security of urban and rural households alike, development of rice growing has long been considered a priority in Nigeria. The country has adopted a range of instruments designed to protect and increase local production. In a bid to also achieve rice self-sufficiency in line with the rice transformation plan, the Federal Ministry of Agriculture and Rural Development (FMARD) have rolled out a special intervention programme on dry season paddy production plan in 2013 (FMARD, 2015). The dry season paddy production is scheduled to take place across ten states particularly Kebbi state and other states namely; Bauchi, Gombe, Jigawa, Kaduna, Kano, Katsina, Kogi, Sokoto and Zamfara.

In the past, several efforts have been made by the Nigeria government to intervene in paddy rice production. Some of these initiatives included presidential initiatives increased rice production (2002-2007); The Africa Rice Initiative, 2012; Nigerian National Rice Development Strategy (NRDS), 2009-2018; Growth Enhancement Support Scheme(GESS) for rice value chain under presidential transformation Agenda 2011 (Osuoha, 2014). Of recent, the ongoing Anchor Borrowers (ABP) Launched by the CBN and the Green Alternatives policy initiated by Federal Ministry of Agriculture and Rural Development (FMARD) in 2016. All these, were expected to widen the home market for the nation's local rice production and decrease demand for imported rice.

Despite all these programs and policy, the quality of rice has become an important issue among Nigerian consumers who clearly show strong concern for imported rice, because of its quality in terms of cleanliness (West Africa Rice Development Association, WARDA, 2015). This has brought about competition of imported rice and locally processed rice. The low quality of locally processed rice reflects low level of improved processing technology and this can reduce the efforts in achieving progress of raising 


\section{Nigerian Journal of Basic and Applied Science (June, 2020), 28(1): 75-84}

output to meet the consumers demand. It is recognized that these attributes are greatly affected by the attention given to pre-milling and post-milling operations. These operations include parboiling, winnowing, padding, drying, destoning, milling, and eventually bagging.

Limited knowledge about the fresh produce postharvest handling practices among farmers has been identified as one of the constraints to improved agricultural productivity, market access and high farm incomes, in which small producers often lack access to critical postharvest knowledge, technology and infrastructure (Obasi \& Enyia, 2016). A focus on post-harvest activities, differential value added products and increasing livelihood with access to market for goods produced by low- income producers would appear to be the strategy open to smallholders (Lundy et al., 2002; Katinka and Thomas; 2005, and Obasi \& Enyia, 2016). The existing gap in poverty in the urban and rural sectors in the SubSaharan Africa has therefore attracted the attention of social scientists to study rural livelihood (Nasa et al., 2010). The objectives of this study were to describe the socio-economic characteristics, estimate the determinants of investment in value addition and its effect on poverty status of rice farmers in Kebbi State, Nigeria.

\section{MATERIALS AND METHOD Description of Study area}

The study was conducted in Kebbi State, Nigeria. The state is located between latitudes $7045^{\prime} \mathrm{N}$ and $9030^{\prime} \mathrm{N}$ and longitude Longitudes $3^{\circ} 35 \mathrm{E}$ and $6^{\circ} 0 \mathrm{E}$. It is positioned in the Semi-arid SudanSahelian ecological zone. However, the Southern portion of the State falls within Northern Guinea Savannah ecological zone. The state is characterized by high temperatures especially in the months of March, April and May. The annual temperature varies from $21^{\circ} \mathrm{C}-38^{\circ} \mathrm{C}$. The soil type found in the state ranges from heavy clay in the fadama areas to sandy loam and sandy soil in the upland areas [Kebbi Agricultural and Rural
Development Authority (KARDA)] Kebbi State has a projected population of 5,048, 815 in 2019. Over $75 \%$ of the state population resides in rural areas and farming is their major occupation. A significant number of urban dwellers also engage in farming to supplement their income (Suleiman, 2007). In addition, the State has a total land area of approximately $36,229 \mathrm{sq}$. km. Out of this, only an estimated $13,209 \mathrm{sq}$. $\mathrm{km}$ is being used for cultivation and about 200,000 ha of fertile land is fadama (wet) land, mainly situated along the flood and mostly used in rice production (Suleiman, 2007, Oladimeji et al., 2016).

\section{Sampling Procedure and Sample Size}

Multi-stage sampling technique was employed in the selection of farmers for this study. The first stage is the purposive selection of three agricultural zones in Kebbi state namely zones A, $B$, and $C$. The purposive selection of these zones was due to their involvement in rice production in the state. The second stage was random selection of one Local Government Area (LGA) each in the three zones and lastly purposeful selection of rice farmers involve in value addition activities from each village to get the sample size. Therefore, a total of one hundred and twentythree (123) farmers were randomly selected as shown in Table 1.

\section{Data collection}

Primary data were used for this study. These were collected with the aid of structured questionnaire, supplement with an oral interview due to low literacy of the respondent. The information was collected on (a) farmers' socioeconomic characteristics such as age, household size and educational level, farming experience, amount of credit received numbers of extension contact, cooperative membership, and farm size. (b) Information on total expenditure for farmers that invest in rice value chain activities and income from the value addition activities. Data collected was analyzed using descriptive statistics, Foster Greek - Thoerboeck Poverty index and Logit regression.

Table 1: Sampling procedure and sample size of rice farmers in Kebbi State 
Hussaini et al: Determinants of Rice Farmers' Investment in Value Addition and Its Effect on.........

\begin{tabular}{|c|c|c|c|c|c|c|}
\hline Zones & LGA & Villages & $\begin{array}{c}40 \% \text { of } \\
\text { villages }\end{array}$ & Name of villages & $\begin{array}{l}\text { Sample } \\
\text { frame }\end{array}$ & $\begin{array}{c}\text { Sample } \\
\text { Size }\end{array}$ \\
\hline \multirow[t]{3}{*}{$\bar{A}$} & Augie & 7 & 3 & Rayau & 123 & 20 \\
\hline & & & & Bagaye & 114 & 7 \\
\hline & & & & Mallamari & 101 & 5 \\
\hline \multirow[t]{6}{*}{ B } & Suru & 15 & 6 & Maikwari & 141 & 7 \\
\hline & & & & Bandam & 187 & 13 \\
\hline & & & & Aljamar & 120 & 6 \\
\hline & & & & Giro & 208 & 20 \\
\hline & & & & Dakingwari & 112 & 5 \\
\hline & & & & Bakindama & 189 & 9 \\
\hline \multirow[t]{2}{*}{ C } & Shanga & 4 & 2 & Dugu & 121 & 6 \\
\hline & & & & Shanga & 253 & 25 \\
\hline Total & & 26 & 11 & & 1669 & 123 \\
\hline
\end{tabular}

Source: Reconnaissance survey, $2017^{*}$ obtained from the state rice farmers' association and ADPs.

\section{Data and Statistical Analysis}

The data for this research were collected from two major sources: primary data were collected with the use of questionnaire instrument, consisting of both closed and open ended questions while secondary information were obtained from journals, internets and past projects.

Data collected from the field was analyzed using descriptive statistics such as frequency, percentages and Foster-Greek-Thorbecke (FGT) indices, and, inferential statistics such as logit regression model.

\section{Model Specification}

\section{Logit Regression Model}

Logit model was selected for this study largely due to its simplicity of calculation and that its probability lies between 0 and 1 . Moreover, its probability approaches zero at a slower rate as the value of explanatory variable gets smaller and smaller and the probability approaches 1 at a slower and slower rate as the value of the explanatory gets larger and larger (Gujarati, 1988; Bola, 2012). The probability that rice farmers will fall below the poverty was postulated as a function of socioeconomic characteristics. Therefore, The underlying response variable $y^{*}$ in the case of binary choice is econometrically specified by the multivariate logit regression relation.

$P_{i}=y^{*}=F\left(Z_{i i}\right)=F(y+\Sigma \lambda 1 \times 1)=\frac{1}{1+e^{-z} 1}-(1)$

Where: $\mathrm{Pi}=$ the probability that a rice farmers will fall below the poverty line, where $y^{*}$ is binary or dichotomous variable which implies that 1 for category of rice farmers above the poverty threshold and 0 for rice farmers below the threshold.

$Z_{1}=$ the function of a vector of $n$ explanatory variables and $e=$ the base of natural logarithms which is approximately equal to 2.718 and $\mathrm{Xi}=$ the ith explanatory variables and are parameters to be estimated.

Hosmer and Lemeshow (1989) pointed out that the Logit Model could be written in terms of the odds and $\log$ of odds which enables one to understand the coefficients. The odds ratio implies the ratio of the probability $(\mathrm{Pi})$ that the probability that a rice farmers will fall below the poverty and $(1-\mathrm{Pi})$ that the rice farmers is not poor.

$\mathrm{Pi}=\frac{1}{1+\mathrm{e}^{-Z}} \ldots .(2)$

$Z_{1}$ is the function of a vector of $n$ explanatory variables and expressed as:

$Z_{1}=\beta_{0}+£ \beta_{1} X_{1}-(3)$ 


\section{Nigerian Journal of Basic and Applied Science (June, 2020), 28(1): 75-84}

Where: $\beta_{0}=$ intercept and $\beta_{1}=$ vector of unknown slope coefficients the relationship between $\mathrm{Pi}$ and $\mathrm{Xi}$, which is non-linear, can be written as follows:

Finally, the logit model is obtained by taking the logarithm of equation as follows:

$\operatorname{Ln}\left(\frac{p}{1-p}\right)=\mathrm{Y}=\mathrm{\alpha}_{0}+\mathrm{B}_{1} \mathrm{X}_{1}+\mu_{\mathrm{i}} . .(4)$

Where: $Y=$ Poverty status $(1=$ poor, $0=$ not poor), $X_{1}=$ net income from value addition (

$a_{0}=$ Constant term, $\beta_{1}=$ coefficient and $\mu_{i}=$ error.

\section{Foster-Greer-Thorbecke (FGT) indices}

Foster-Greer-Thorbecke (FGT) indices were used to determine the poverty level of the rice farming households, the FGT poverty index developed by Foster et al. (1984) was adopted. Thus, $\mathrm{Pa}=\frac{1}{n} \sum_{i=1}^{q}\left(\frac{z-y_{1}}{z}\right)^{\alpha} \ldots . .(5)$

Where:

$\mathrm{Pa}$ is the FGT poverty index for the ith subgroups, $n$ is the total number of households in the ith subgroup households, $Y i$ is the expenditure of $i$-th household, $z$ is the poverty line, $q$ is the number of the sampled household population below the poverty line and $a$ is the aversion to degree of concern (a co-efficient reflecting different degrees of importance accorded to the depth of poverty and it ranges from 0 to 2 . When the aversion to poverty (a) is equal to zero, it implies no concern and the equation gives the head count ratio for the incidence of poverty (the proportion of the rice farming households that will be below the poverty line). When it is expressed in percentages, it is the incidence of poverty in the population. The headcount ratio has been criticized for focusing only on the number of the poor and being insensitive to the severity of poverty and to change below the poverty line. That is, it treats all the poor equally, whereas not all poor are equally poor.

That is,
Poverty headcount index $(a=0)$

Poverty depth $\mathrm{P}_{0}=\frac{1}{n} \sum_{i=1}^{q}\left(\frac{z-y_{1}}{z}\right)^{0}=\frac{q}{n} \ldots(6)$

When $a$ is equal to 1 , it shows uniform concern and equation become

Poverty Gap $\mathrm{P}_{1}=\frac{1}{n} \sum_{i=1}^{q}\left(\frac{z-y_{1}}{z}\right)^{1} \ldots \ldots .(7)$

Poverty severity $\mathrm{P}_{2}=\frac{1}{n} \sum_{i=1}^{q}\left(\frac{z-y_{1}}{z}\right)^{2} \ldots(8)$

This measure the depth of poverty (the proportion of expenditure shortfall from the Poverty line) according to Hall and Patrinos (2005), it is otherwise called the poverty gap or expenditure gap- the average difference between the income and the poverty line.

Although superior to the headcount ratio, $P_{1}$ still implies uniform concern about the depth of poverty, in that it weighs the various expenditure gaps of the poor equally. The poverty gap index $P_{1}$ was used to measure the depth of poverty of the rice farmers' households in Kebbi State. When a is equal to 2 distinction is made between the poor and the poorest, that is, the Severity of poverty (Foster, Greek and Thorbecke, 1984)). The equation becomes:

Poverty severity $P_{2}=\frac{1}{n} \sum_{i=1}^{q}\left(\frac{z-y_{1}}{z}\right)^{2} \ldots(9)$

The equation gives the concern for incidence and the distribution of the depth of poverty and its relative importance. It gives a distinction between the poor and the poorest rice farmers households in Kebbi State. That is, the severity of poverty and extent of poverty distribution among the rice farming households in the state. The poverty line that was used for this study was defined as the two-thirds of mean Household expenditure per adult equivalent. Household expenditure is considered as an adequate measure of household welfare, in developing countries as it better able to capture households' consumption capabilities (Bogale et al., 2005). Accordingly, a household is considered as poor when household 
expenditure is insufficient to meet the food and other basics needs of all household.

\section{RESULTS AND DISCUSSION}

The result in Table 2 showed the socio economic characteristics of the rice farmers in Kebbi State. The average age of the rice farmers was 46 years and a standard deviation of approximately 10. This implies that majority of the rice farmers in the State were middle age, energetic and there is likelihood of increase of productivity in rice production. Ceteris paribus, if productive age group is defined as 21-60 years, rice farmers in the study area should be able to imbibe new ideas and innovations to enhance increased productivity in the industry. Moreover, $61 \%$ of the farmers attained some form of education. This could have affected their chances of using improved and inputs which can boost rice output. Therefore, rice farmers in the study areas would be receptive to innovations to boost rice production and hence, profit level. Average number of persons per rice farmer was approximately 11 , with standard deviation of 5.8. The size of the household affects the amount of farm labour of household and often affects household food security. The average value of farming experience was 24 years with the standard deviation of 8.98. Conversely, the analysis of years of experience shows that there were more new entrants into the farming activities is the study area. This was attributed to the drift of youth to farming as a result of lack of white collar job after finishing schools. However, years of farming experience as observed by (Oladimeji et al., 2014) is a factor that enhances agricultural productivity among farming households in Nigeria. The result further shows Farmers had an average of 7 years of membership of cooperatives in the study area.

$\mathrm{P}_{0}$ shows the proportion of the population that falls below the poverty line, $P_{1}$ is the average depth of poverty for the poor and the $\mathrm{P}_{2}$ shows the severity of poverty in each case. The result shows that $58.36 \%$ of sampled respondent are below poverty line. The result also indicates that the poverty gap and severity of poverty were 0.211 and 0.07 respectively.

Table 2. Socio economic characteristics of rice farmers in Kebbi State

\begin{tabular}{lllllll}
\hline Socioeconomic characteristic & Unit & Mean & Min value & Max value & Stdev & CV \\
\hline Age & Years & 46 & 25 & 70 & 9.9 & 21.6 \\
Household size & Persons & 11 & 1 & 35 & 5.8 & 48.3 \\
Farming experience & Years & 25 & 5 & 52 & 8.98 & 36.83 \\
Education & Years & 0.67 & 0 & 15 & 2.0 & 33.5 \\
Cooperative membership & (Years) & 7 & 0 & 25 & 5.82 & 82.9 \\
\hline
\end{tabular}

\section{Extent of poverty among the Rice farmers:}

Table 3 show the decomposition of poverty status of the rice farmers in Kebbi State.

Table 3. Decomposition of poverty status of rice farmers in Kebbi State

\begin{tabular}{ll}
\hline Variables & Frequency \\
\hline Poverty line(\#) & $31,733.40$ \\
Poverty headcount & 0.58 \\
Poverty gap & 0.21 \\
Poverty severity & 0.07 \\
Poor & 58.3 \\
Non-poor & 42.7 \\
\hline
\end{tabular}




\section{Effects of value addition activities and its effect on poverty status}

The result of the logistic model used to determine the effects of value addition on poverty status of rice farmers in Kebbi State are presented in Table 4. The likelihood ratio test was -61.01727 with one degree of freedom. This implies that the variable included in the Logit model (NI) had significant influence on poverty status. The McFadden R-square was 0.282 , implying that $28.2 \%$ in the effect of value addition on poverty status in the study area was explained by the explanatory variables (additional income) specified in the model. The F-value of 0.528 was statistically significant at $1 \%$ probability level and this indicates the joint significance of the specified variable on poverty status to value addition in the study area. The marginal effects from the model, measured the expected change in probability of a particular choice being made with respect to a unit change in an independent variable.

The result of the analysis showed that the marginal effects of income from parboiling, winnowing, drying, destoning, and bagging value addition were negative and statistically significant related to farmer's poverty status at $1 \%$ level. An increase in this value addition income by one unit reduces the probability of a farmer becoming poor by 0.00265 units. This implies that farmers that participate in this aspect of value addition activities are likely to be better off due to the additional income from their involvement in these activities. The additional income has been found to reduce poverty levels through its positive contribution to welfare indicator. Similarly, offfarm income was negative and a unit increase in this value addition income by one unit reduces the probability of a farmer becoming poor by 0.14547 units. This is in line with the findings of Berem (2009) and Oladimeji et al. (2015) who asserted additional income as an important determinant of poverty and reported that an increase in off farm activities will lead to extra household income which could reduce the poverty level of the farmers. Umeh (2013) also revealed that cassava value addition has positive influence on the income generation of farm household in Etinam LGA of Akwa lbom State of Nigeria.

\section{Constraints Encountered by Rice Farmers in Value Addition Activities}

Table 5 showed the problems faced by rice farmers in in Kebbi State and were ranked according to the magnitude as stated by the farmers. High cost of labour was ranked to be the most critical constraint by about $81 \%$ while, about $75.6 \%$ of farmers indicate poor marketing information as the most serious constraint limiting the farmers in engaging in value addition activities.

Table 5. Logistic estimates of determinant of poverty status of rice farmers in Kebbi State

\begin{tabular}{|c|c|c|c|c|}
\hline \multicolumn{2}{|l|}{ Variable } & $\begin{array}{l}\text { Marginal } \\
\text { effects }\end{array}$ & SE & $P>|Z|$ \\
\hline \multicolumn{2}{|c|}{ Constant } & 0.346294 & 4.72103 & 0.9001 \\
\hline \multicolumn{2}{|c|}{ Y from parboiling, winnowing \& drying } & -0.00050 & 0.00057 & -0.107 \\
\hline \multicolumn{2}{|c|}{ Y from parboiling, winnowing, drying \& destoning } & -0.688366 & 0.4508 & -0.100 \\
\hline \multicolumn{2}{|c|}{ Y from parboiling, winnowing, drying, destoning \& bagging } & -0.00265 & 0.00075 & -0.000 \\
\hline \multicolumn{2}{|c|}{ Education } & -0.31331 & 0.51113 & -0.100 \\
\hline \multicolumn{2}{|l|}{ Off farm income } & 0.14547 & 0.54324 & 0.000 \\
\hline \multicolumn{2}{|l|}{ Household size } & -0.03332 & 0.3713 & -0.119 \\
\hline Log likelihood test & -61.01727 & & & \\
\hline F-distribution & 0.528 & & & \\
\hline Mcfadden R-square & 0.2820 & & & \\
\hline Prob. $>\mathrm{Chi}^{2}$ value & 0.000 & & & \\
\hline
\end{tabular}

Note: ** statistically significant at $5 \%$ level of probability, $Y$ denote Income, SE Standard Error 


\section{Hussaini et al: Determinants of Rice Farmers' Investment in Value Addition and Its Effect on.........}

Table 4. Constraints encountered by rice farmers in Kebbi State

\begin{tabular}{llll}
\hline Constraints & Frequency & Percentage & Rank \\
& & & \\
\hline High cost of labour & 100 & 81.3 & $1^{\text {st }}$ \\
Poor marketing information & 93 & 75.6 & $2^{\text {nd }}$ \\
Inadequate credit & 90 & 73.1 & $3^{\text {rd }}$ \\
Inappropriate method of processing & 85 & 69.1 & $4^{\text {th }}$ \\
Inadequate access to good road & 79 & 64.2 & $5^{\text {th }}$ \\
\hline
\end{tabular}

Multiple choices is allowed

Suffice to note that improved access to input and output markets is a key precondition for the transformation of the rice sector from subsistence to commercial production. Small scale rice farmers must be able to benefit more from efficient markets and local-level value addition, and be more exposed to competition.

Inadequate credits were ranked the third $(73.1 \%)$ by the rice farmers in the study area. Credit is one of the policy instruments considered to facilitate technology transfer, stimulate productivity, and generate employment and increase income (Oladimeji et al., 2015). Credit constraints affect farmer's investment behaviors, productivity and expansion of farms negatively.

About $69 \%$ of the rice farmers indicated inappropriate method of processing which rank the fourth. .This affect the investment in value addition activities as the farmers are still used the traditional method of processing in the study area. About $64 \%$ of the farmers indicate inadequate access of good road as constraints in the study area. Distribution of inputs and outputs to and from farms is the most serious infrastructural bottleneck facing agricultural development in Nigeria. Majority of the rice farmers sell immediately after harvesting and acquired their inputs at unavoidable price with little choice of where they conduct the transactions, with whom and at what price. Therefore, the rice farmers need access to competitive markets not just for their produce but also for inputs, assets and technology, consumer goods, credit and labour.

\section{CONCLUSION}

The study revealed that poverty level among the rice farmers was high and that socio-economic and institutional variables were important factors influencing poverty status of rice farmers in the study area. It could be concluded that income from rice value addition has positive effects by alleviating the poverty status of sampled rice farmers in Kebbi State. High cost of labour, poor marketing information and inadequate credit were identified as the three most critical constraints limiting the farmers in engaging in value addition activities.

\section{EFERENCES}

Adu, E. A., Isiaka, A. A., Awagu, E. F. \& Aminu M. D. (2012). Study on the level of mechanization of rice processing in Kano State, Nigeria. International Journal of Engineering Research \& Technology, 1(10): 1-15.

Ala, A. L. \&. Bello, F. A. (2010). Contribution of food crops to household food security among crop farmers in Patigi Local Government Area, Kwara State, Nigeria. Nigerian Journal of Basic and Applied Science, 18(2): 193-197.

Berem, R. M. (2009). Analysis of the Constraints and Effects of Value Addition in Honey Among Producers in Baringo District, Kenya. A PhD Thesis Submitted Egerton University, Kenya. 267pp.

Bogale, A., Hagedorn, K. and Korf, B. (2005). Determinants of poverty in rural Ethiopia. 


\section{Nigerian Journal of Basic and Applied Science (June, 2020), 28(1): 75-84}

Quarterly Journal of International Agriculture, 44(2): 101-120.

Bola, A. W. (2012). Poverty and income inequality among fish farming households in Oyo State, Nigeria. Medwell Agricultural Journal, 7(2): 111-121.

Federal Ministry of Agriculture and Rural Development, (2011). "Agricultural Transformation Agenda: We Will Grow Nigeria's Agricultural Sector." Abuja: Presentation by Minister of Agriculture, Federal Government of Nigeria publication.

Foster, J. J., Greer, J. and Thorbecke, E. (1984). A class of decomposable poverty measures. Econometrica, 52: 761-765.

Gujarati, D. (1988). Basic Econometrics. 2nd Edition, McGraw Hill Book Company, New York.

Gyimah, K., Michael, J. \& Hiroyuki, T. (2016). The Nigerian Rice Economy: Policy Options for Transforming Production, Marketing and Trade. Philadelphia: University of Pennsylvania Press.

Hall, G. and Patrinos, H. A. (2005). Latin America's indigenous people: a time of transition, finance and development. International Monetary Fund, 42: 24.

Hosmer, D. W. and Lemeshow, S. (1989). Applied Logistic Regression. Wiley Interscience Publication, New York, USA. 103pp.

Ige, M. M., Baruwa, O. I. \& Akintelu, S. O. (2016).Techno-economic assessment of rice agribusiness in selected States of Southwestern Nigeria. Nigerian Journal of Agriculture, Food and Environment, 12(3): 28-36.

Isaac A., Gerald, A., Etornam, K. A. and Ernest, K.(2016) Postharvest handling practices and treatment methods for tomato handlers in developing Countries: A mini review International Journal of Agronomy 6:1-6.

John, K. M, Kuwornu, M. B. \& Moses, D. (2014). Farm households' livelihood diversification into agro-processing and non-agro processing activities: empirical evidence from Ghana Information Management and Business Review, 6(4): 191-199.

Johnson, M. \& Masias, I. (2017). Assessing the state of the rice milling sector in Nigeria: the role of policy for growth and modernization, feed the future innovation lab for food security policy. Nigeria Agricultural Policy Project Research Paper 59.

Katinka, M. W. \& Thomas, A. L. (2005). Diversification into horticulture and poverty reduction: A Research Agenda World Development, 35(8): 1464-1480.

Kindness, H. \& Gordon, A. (2001). Agricultural Marketing in Developing Countries: The Role of NGOs and CBOs. Policy Series 13, Natural Resources Institute; University of Greenwich.

Lundy, M., Felipe, C. \& Best, R. (2002). Value Adding, Agro enterprise and Poverty Reduction: A territorial approach for Rural Business Development. Rural Agro enterprise Development Project, CIAT. Colombia. $12 p p$ $\mathrm{http} / / \mathrm{www}$.ciat.cgiar.org/agroempresas/in gles/index.htm.

Ministry of Food \& Agriculture. (2007). Food and Agricultural Sector Development Policy, (FASDEP II) Publication.

Nasa, D. H., Atala, T. K., Akpoko, J. G. \& Kudi, T. M. (2010). Analysis of factors influencing livelihood diversification among rural farmers in Giwa Local Government Area of Kaduna State, Nigeria. International Journal of Science and Nature, 1(2), 161-165.

Obasi, P. C. \& Enyia, C. O. (2016). Analysis of value addition and livelihood diversification among fadama users in Imo State, Nigeria. Federal University Technology Owerri Journal 2(2), 236 251.

Oladimeji, Y. U., Damisa, M. A., Abdulsalam, Z. \& Omokore, D. F. (2014). A micro level analysis of poverty among artisanal rural 
fishery in Kwara State, Nigeria, Ethiopia. Journal of Environmental Studies \& Management, 7(4): 423-433.

Oladimeji, Y. U., Abdulsalam, Z. \& Abdullahi, A. N. (2015a). Determinants of participation of rural farm households in non-farm activities in Kwara State, Nigeria: a paradigm of poverty alleviation. Ethiopian Journal of Environmental Studies and Management, 8(6): 635 - 649 .

Oladimeji, Y. U., Ajao, A. M., Abdulrahman, S., Suleiman, R. \& Bolaji, A. M. (2016).Estimation of efficiency differentials in honey bee enterprises: implications for higher productivity in Kebbi and Kwara States of Nigeria. Gashua Journal of Irrigation and Desertification Studies, 2( 2): 2489.

Osuoha, S. A. (2014). Analysis of government initiatives on rice production in Nigeria. Journal of Advances in Science and Technology, 2(6): 89-93.

Suleiman, A. (2007). Economic Analysis of Artisanal Fish Marketing In Kebbi State of Nigeria.Unpublished Ph.D Dissertation, Ahamadu Bello University, Zaria, Nigeria. 279Pp
Ugwu, J. N., Mgbakor, M. N. \& Chitor, C. C. (2014). Assessment of value addition in rice and processing in Adani Uzouwani Local Government Area of Enugu State, Nigeria International Journal of Agriculture Science \& Veterinary Medicine, 2(4), 53-68.

Umeh G. N. (2013). Effect of cassava value addition on the income generation of farm households in Etinam local government area of Akwa Ibom State, Nigeria International Journal of Science and Research (IJSR), 4(8): 1346-1349.

Umeh, J. C. \& Ataborh, E. M. (2007). Efficiency of rice farmers in Nigeria: potentials for food security and poverty alleviation. International Farm Management Congress, 16(3): 613-6.

WARDA. (2015). Essence of WARDA, the reason why Nigerians are hooked to rice women's involvement in the agroprocessing enterprise of the national special programme for food security in Imo State, Nigeria. Report and Opinion, 2(7): 69-73. 